\title{
Substitusi Tepung Pucuk Indigofera zollingeriana dengan Bungkil Kedelai Terhadap Peforma Produksi Puyuh Petelur Pemeliharaan 8 Minggu
}

\author{
Fira Faradillah \\ Program Studi Fakultas Peternakan, Universitas Muhammadiyah Tapanuli Selatan \\ Email: fira.faradillah@um-tapsel.ac.id
}

\begin{abstract}
The study used 200 Japanese quail (Cortunix Cortunix japonica) aged eight weeks with a daily egg production of $>50 \%$. This research aimed to study the substitutions of soybean meal (SBM) with Indigofera zollingeriana top leaf meal (ILM) in the diet on of the quail production performance. The experiment was conducted using a complete random design with five treatments and four repeats (10 quail tails each). The dietary treatment contained fve kind of combination of of SBM and ILM, R0= diets contained 18\% SBM without ILM, R1=16.2\% SBM and 2.66\% ILM, R2= 14.4\% SBM and 5.32\% ILM, R3 $=12.6 \%$ SBM and 7.98\% ILM, $\mathrm{R} 4=9 \%$ SBM and 13.3\% ILM. The result showed that the used 2.66\%, 5.32\%, 13.3\% ILM $(\mathrm{R} 4)$ significantly $(\mathrm{P}<0.05)$ to quail egg production, egg mass production, and ration conversion. The conclusion of this sstudy was Indigofera zollingeriana top leaf meal could be used as much as $13.3 \%$ in the diets and could improve the quail production performance.
\end{abstract}

Key words : Indigofera zollingeriana, Production performance Quail,

\section{PENDAHULUAN}

Telur merupakan salah satu produk peternakan yang dapat dijadikan sumber protein hewani. Puyuh petelur (Coturnix coturnix japonica) merupakan jenis unggas yang memiliki produktivitas tinggi. Bahan pakan merupakan sesuatu yang sangat penting dalam usaha peternakan. Pembuatan ransum untuk memenuhi kebutuhan protein, energi dan nutrisi mikro unggas dapat diperoleh dari gabungan beberapa bahan pakan sumber hewani maupun nabati. Pemenuhan permintaan bahan pakan protein yang bersumber dari bungkil kedelai dan tepung ikan sampai saat masih menjadi kendala perternak karena harganya mahal. Menurut Ditjen PPHP (2014) Indonesia impor 3.53 juta ton bungkil kedelai sebagai pakan sumber protein nabati untuk memenuhi kebutuhan bahan pakan ternak. Penggunaan bahan pakan sumber protein yang berasal dari hijauan cukup populer beberapa tahun belakangan. Seperti penggunaan daun katuk dan murbei dalam ransum tidak mempengaruhi profil darah puyuh (Marsiz, 2011). Daun katuk dapat menurunkan kolesterol telur (Subekti et al., 2006). Penggunaan $\quad 13,3 \% \quad$ Indigofera zollingeriana dalam ransum puyuh meningkatkan bobot telur, warna kuning 
telur dan menurunkan kandungan malondialdehyde (Faradillah et al., 2015).

Indigofera zollingeriana memiliki kandungan nutrisi yang baik, sehingga berpotensi dijadikan sebagai bahan pakan. Menurut Faradillah et al., (2015) I. zollingeriana memiliki kandungan protein kasar $28.41 \%$, serat kasar $13.45 \%$ dan lemak kasar $1.08 \%$. Tanaman ini merupakan hijauan leguminosa dan dapat dijadikan sebagai sumber protein. Selain kandungan protein yang tinggi jenis leguminosa ini juga memiliki kandungan betakaroten $507.6 \quad \mathrm{mg} / \mathrm{kg}$ sebagai antioksidan, $\alpha$-tocoperol $148.74 \mathrm{mg} / \mathrm{kg}$, vitamin D $42.46 \mathrm{mg} / 100 \mathrm{~g}$, vitamin K 1.149 ppm (Palupi et al., 2014). Berdasarkan potensi yang dimiliki I. zollingeriana maka dilakukan penelitian dengan memanfaatkan tepung pucuk I. zollingeriana sebagai substitusi bungkil kedelai di dalam ransum untuk Peforma Produksi Puyuh.

\section{MATERI DAN METODE}

Penelitian ini menggunakan 200 ekor puyuh petelur (Coturnix coturnix japonica) betina berumur delapan minggu dengan bobot rata-rata $143.83 \pm 3.92$ g ekor1

dengan produksi telur harian $>50 \%$. Sebanyak 20 unit kandang percobaan digunakan untuk masing 10 ekor puyuh dengan ukuran $60 \mathrm{~cm}$ x $40 \mathrm{~cm}$ x $20 \mathrm{~cm}$. Setiap cage dilengkap dengan tempat pakan, minum, thermometer digital, lampu pijar. Peralatan lain yang digunakan adalah timbangan digital (Osuka-HWH ${ }^{\circledR}$, Japan), tirai dan bak sanitasi. Seluruh kandang disanitasi sebelum kandang ditempati puyuh.
Ransum diberikan dalam bentuk mash dengan nutrient ransum didasarkan kepada kebutuhan puyuh fase produksi menurut NRC (1994), dengan isoprotein $20 \%$ dan isoenergi metabolis $2900 \mathrm{kkal} / \mathrm{kg}$. Penelitian ini menggunakan rancangan acak lengkap (RAL) lima perlakuan dan empat ulangan. Formulasi dan kandungan nutrisi ransum berdasarkan Faradillah et al (2015), bahan pakan penyusun ransum adalah jagung kuning, dedak padi, bungkil kedelai, tepung pucuk I. zollingeriana, corn gluten meal, tepung ikan, minyak, $\mathrm{CaCo} 3$, Premik, $\mathrm{NaCl}$, DL-metionin, L-lisin dan calcium phospat.

\section{Metode}

Puyuh dipelihara selama 56 hari, ransum diberikan secara ad libitum. Telur diambil dua kali dalam sehari, pada pukul 08.00 WIB dan 17.00 WIB, ditimbang dan hitung jumlah telur yang diperoleh untuk menentukan quail day. Untuk menjaga kebersihan, kandang dibersihkan setiap pagi kemudian lakukan pemberian air minum pada pukul 06.00 WIB.

\section{Ransum Perlakuan Penelitian}

Perlakuan yang digunakan adalah substitusi tepung pucuk I. zollingeriana dengan bungkil kedelai. $\mathrm{R} 0=$ Ransum mengandung $18 \% \quad \mathrm{BK}$ dan $0 \% \quad \mathrm{TPI}$ (Ransum kontrol), R1= Ransum mengandung $16.2 \%$ BK dan $2.66 \%$ TPI (Substitusi $10 \%$ protein BK dengan protein TPI), R2= Ransum mengandung 14.4\% BK dan 5.32\% TPI (Substitusi 20\% protein BK dengan protein TPI), R3= Ransum 
mengandung $12.6 \%$ BK dan $7.98 \%$ TPI (Substitusi 30\% protein BK dengan protein TPI), R4= Ransum mengandung 9\% BK dan $13.3 \%$ TPI (Substitusi 50\% protein BK dengan protein TPI)

\section{Peubah yang diamati}

\section{Peforma Produksi}

a. Produksi telur harian/ quail day production (\%). Produksi telur harian dihitung dengan membagi jumlah telur pada hari yang bersangkutan dengan jumlah puyuh yang hidup pada hari yang sama dikali $100 \%$.

$$
\text { Quail day production }=\frac{\text { Jumlah telur }}{\text { Jumlah jumlah puyuh }} \text { X } 100 \%
$$

b. Produksi massa telur (g ekor-1). Massa telur dihitung berdasarkan jumlah telur yang dihasilkan dikalikan dengan berat telur selama penelitian.

c. Konversi ransum, dihitung dengan cara:

$$
\text { Konversi ransum }=\frac{\text { Konsumsi ransum }\left(\mathrm{g} \mathrm{ekor}^{-1}\right)}{\text { Produksi massa telur }\left(\mathrm{g} \mathrm{ekor}^{-1}\right)}
$$

\section{Analisis Data}

Pada penelitian ini data dianalisis menggunakan Statistical Package for Social Sciences (IBM®SPSS ${ }^{\circledR}$ version 21.0). One-way analisis of variance (ANOVA) digunakan untuk menentukan taraf berbeda nyata, perbedaan dianggap signifikan pada $(\mathrm{P}<0.05)$ dan uji jarak Duncan dilakukan jika berbeda nyata (Mattjik dan Sumertajaya 2006).

\section{HASIL DAN PEMBAHASAN}

Gambaran peforma produksi puyuh dengan substitusi tepung pucuk Indigofera zollingeriana (TPI) dengan bungkil kedelai dapat dilihat pada tabel 1. Rataan produksi telur yang optimal pada penggunaan $0 \%$ $5.32 \%$. Stabil atau tidaknya produksi telur dipengaruhi oleh aktivitas puyuh mempertahankan keseimbangan panas. Antioksidan yang terkandungan di dalam TPI memiliki peran sebagai pereda stress (Palupi et al., 2014). Jika dibandingkan dengan kontrol substitusi TPI dengan bungkil kedelai berpengaruh $(\mathrm{P}<0.05)$ terhadap produksi telur harian puyuh.

Rataan produksi telur harian dengan pemberian $2.66 \%, 5.32 \%$, $13.3 \%$ tepung pucuk Indigofera zollingeriana substitusi protein bungkil kedelai adalah jumlah produksi yang tinggi jika dibandingkan dengan kontrol (R0) 63.49\%. Produksi telur tertinggi terdapat pada perlakuan $13.3 \%$ TPI dalam ransum yaitu $75.06 \%$. Turunya produksi telur pada unggas dipengaruhi oleh suhu yang mengakibatkan stress (Rosa et al., 2011). Menurut Faradillah et al., (2015) penggunaan 13,3\% tepung pucuk Indigofera zollingeriana meningkatkan konsumsi puyuh. Produksi telur erat hubunganya dengan konsumsi.

Massa telur berkorelasi dengan bobot dan produksi telur (Vercese et al., 2012). Hasil penelitian menunjukan substitusi $5.32 \%$ dan $7.98 \%$ TPI dalam ransum dengan bungkil kedelai nyata $(\mathrm{P}<0.05)$ meningkatkan produksi massa telur. Konversi ransum adalah jumlah ransum yang dikonsumsi puyuh dibagi dengan jumlah produksi massa telur. Penggunaan TPI sebagai substitusi bungkil kedelai berpengaruh nyata $(\mathrm{P}<0.05)$ terhadap konversi ransum. sebanyak $13.3 \%$ 
TPI dalam ransum menghasilkan konversi ransum dengan angka yang paling kecil jika dibandingkan dengan perlakuan lain. Keadaan ini disebabkan oleh konversi ransum meningkat sementara produksi massa telur rendah (Faradillah et al., 2015). Menurut Leeson and Summers (2008) angka konversi ransum dipengaruhi oleh produksi telur, bobot telur, kandungan nutrisi ransum, dan suhu.

\section{KESIMPULAN}

Tepung pucuk Indigofera zollingeriana dapat digunakan sebanyak $13.3 \%$ dalam ransum. Substitusi protein Indigofera zollingeriana dengan protein bungkil kedelai dalam ransum dapat meningkatkan peforma produksi puyuh petelur.

\section{DAFTAR PUSTAKA}

Faradillah F, Mutia R, Abdullah L. 2015. Substitution of Soybean Meal with Indigofera zollingeriana Top Leaf Meal on Egg Quality of Cortunix Cortunix Japonica. Media Peternakan: 38(3):192-197.

Leeson S, Summers JD. 2008. Commercial Poultry Nutrition. 3rd Ed. Departement of Animal and Poultry Science, University Guelph. University Books

Canada.

Marsiz AJ. 2011. Pengaruh Konsumsi Protein dan Mineral Besi (Fe) terhadap Profil Darah Puyuh yang Diberi Tepung Daun Katuk dan Murbei dalam Pakan. Skripsi Departemen Ilmu Nutrisi dan Teknologi Pakan, Fakultas
Peternakan, Institut Pertanian Bogor.

Mattjik AA, Sumertajaya IM. 2006. Perancangan percobaan dengan aplilkasi SAS dan MINITAB. Jilid I. Edisi ke-2. Institut Pertanian Bogor (IPB). Bogor. Pr.

National Research Council. 1994. Nutrient Requirement of Poultry. Revised Edition. National Academy Press, Washington DC.

Palupi R, Abdullah L, Astuti DA, Sumiati. 2014. Potential and utilization of Indigofera sp. shoot leaf meal as soybean meal substitution in laying hen diets. JITV. 19(3):210-219.

[Ditjen PPHP]. Direktorat Jendral Pengolahan dan Pemasaran Hasil Pertanian.

2014. Kementerian Pertanian Republik Indonesia. Jurnal statistik Ekspor

Impor Komoditas Pertanian. ISSN: 2337-9578.

Rosa GA, Sorbello LA, Dittrich RL, Moraes MTT, Oliveira EG. 2011. Blood

profile of japanese quail (Coturnix japonica) under thermal stress. Ciencia

Rural, Santa Maria. 41(9):16051610

Statistical Package for Social Sciences. 2012. IBM SPSS 21.0 for windows (SPSS

Inc., United States)

Subekti S, Piliang, WGW, Manulu BT, Murdiati. 2006. Penggunaan tepung daun katuk dan ekstark daun katuk (Sauropus adrogynus L. merr) sebagai subsitusi ransum yang dapat menghasilkan produk puyuh Jepang rendah kolesterol. JITV, 11: 254259. 
Vercese F, Garcia EA, Sartori J, Silva AdP, Faitarone A, Berto D, Molino AdB, Pelícia K. 2012. Performance and egg quality of Japanese quails submitted

to cyclic heat stress. Revista Brasileira de Ciência Avícola. 14(1):37-41 